\title{
Intermodal Nodes for the European Metropolis: Amsterdam Zuidas as EURandstad's Gate
}

\author{
Manuela Triggianese ${ }^{1, a}$, Fabrizia Berlingieri ${ }^{2, b}$ \\ 1Julianalaan 134, 2628 BL Delft, Netherlands \\ ${ }^{2}$ Piazza della Libertà, Rende (CS), Italia \\ am.triggianese-1@tudelft.nl, binfo@berlingieriarchitetti.it
}

Keywords: Intermodal Node, Infrastructure and Urban Fabric, Urban Policy and Design.

\begin{abstract}
Since more than fifty years, in the Netherlands, the Randstad Holland [1,2] represents a model of reference within the international debate on the sustainable balance between urban areas, infrastructural development and preservation of natural environment. The polycentric urban structure of the country progressively built up a new metropolitan reality of Europe, based on a stable configuration of cities' spatial relations around the maintenance of the Green Hearth core and on strategic logics of infrastructural developments. However today the double awareness to rebalance growing population of urban areas and to open the region towards North-Central Europe, create fundamental conditions for a renewed expanding vision [3].

The current Dutch metropolitan perspective looks at the densest cities of Amsterdam and Rotterdam as main European and international gates, addressing large scale ambitions to clusters of urban developments at the intersection of main roads, railways and local infrastructures.

This paper presents an investigative approach and intends to provoke academic discussion on the conflicting and possible relationships between urban policies and design strategies in the construction of a new metropolitan European perspective. Particular emphasis is put on the coordination between contemporary policies with spatial implications in the city of Amsterdam. Exploring its geographical advantages, the City tries to give form to policies' abstraction of Randstad 2040 vision in the recent structural spatial Agenda, focused on strategic urban and economic cores. The current vision represents the metropolitan ambition of the Netherlands, where the project of Zuidas - literally South Axis - is a prime example of a new model of intermodal urban $h u b$. Throughout the Dutch example, this paper attempts to present Zuidas testing its capability to enhance an innovative approach - in urban policy and spatial implication- to sustainable development.
\end{abstract}

\section{Design and Policy in the construction of the Randstad Metropolitan Region}

Since the Second World War the spatial planning and the urban development in the Netherlands carefully follow a double line based on the reciprocity and the interaction between policies and projects, presenting as result, in a long term perspective, an explicit model for sustainable development within a great balance between urban, rural and natural areas. The key element of this model lies in a clear strategy of access to mobility, having in the infrastructural development its strongest tool to organize a poly-nuclear urban structure of major cities by a multilayered net of public and private infrastructures. The constant dialogue between policies, spatial planning and strategic urban interventions has its major expression in three significant moments.

Starting from the beginning of nineties, the Vierde Nota [4] National Policy reinforced the idea of the Randstad as a spatial structuring concept to reach a more economical competitive position. The goal was addressed by the strategy of implementing major cities' higher density, through public-private partnerships actions aimed at increasing urban transformation developments. In 1992 this policy was subsequently supplemented by the Vinex strategy [5] a program of new residential areas conceived as autonomous entities in rural areas and as alternatives to the urban densification. However it constituted, within the architectural and urban debates, a failure for the consequences 
that the new urban clusters produced on rural areas and on the preserved natural environment Green Belt. The significant critique to this strategy was pointed by the urban research Patchwork Metropolis, revealing a growing phenomenon of sprawl mostly located along main infrastructural lines [6]. It opened an intensive period of urban design researches at National level about the necessity of densifying urban areas instead of reinforcing the sprawl system in future development strategies [7]. Furthermore the infrastructural development began its major course as key strategy to address a new concept of urban density and metropolitan condition for the region.

The second important moment appeared at the beginning of XXI century. Following the National policy of Vijfde Nota [8], focused on the implementation of a multimodal and integrated accessibility through the development of clusters along infrastructural corridors, the architectural debate was questioning about the possible image envisioned for the new infrastructural and high dense metropolitan region [9].

Therefore the emerging vision of Delta Metropolis, promoted by a small group of urban planners and designers in 2000, redefined a more complex concept of metropolitan network through the use of overlapping layers or strata as interrelated components of an integrated vision of the region. Urban networks, geological structures, water flows, ecological and human flows are the multiple layers sliding over each other. This design actor platform, know as Deltametropool Association, bridging the gap between design and policy, was deeply influencing politics to push the concept of Delta Metropolis as instrumental for further urban development issues [10].

Finally at the end of the last decade, the strategic vision of the National Spatial Planning, the Nota Ruimte [11], was embedded by a new idea of context, inserted within the European metropolitan scale and long-term policies. The vision drops the Delta Metropolis concept in favor of an implementation of the Randstad into the north and south wings, which can be seen as separated poly-nuclear city-regions of semi-metropolitan density. Furthermore the new perspective of expanding the Randstad towards national borders and North-Central Europe was envisioned by a double strategy. The first is based on the rebalance of the urban population with the inclusion of the two urban axis of the wings, the Haarlmmermeer-Schiphol-Zuidas-Almere axis and the BredaEindhoven-Tilburg axis, together with infrastructural projects as main activators of the metropolitan strategy. Secondly the new vision pushed Randstad's major cities towards a multi scalar dimension through the upgrading of main intermodal urban hubs, along the high speed line: Rotterdam City, with the development of its harbor and the Central Station District, and Amsterdam, with Schiphol Airport implementation and the transport node Amsterdam Zuidas. [12]

Therefore current policy visions have been translated by means of place-based model and longterm projects. In the new approach the investments in key areas, such as infrastructure and complex urban interventions, are strongly coordinated and focus on city-region relationships towards the development of its metropolitan reality.

\section{From Green Heart to Green Blue Delta}

Recent years have been full of discussions on whether the Randstad still exists as an entity with a Green Heart core or whether it really does consist of separate wings in a patchwork metropolitan region. The current Randstad 2040 Structural Vision makes the Green Heart part of a large GreenBlue Delta, being so protected, developed and made climate-resilient by steering development towards a different kind of integrated dimension. [13] The traditional picture, of a single open zone surrounded by cities, will be replaced by multi diversity in accordance to an area-specific approach. The future picture is of a green-blue backbone interwoven with economic clusters, such as agriculture, housing, work and leisure activities, and with functions such as nature, water storage and cultural history. This development will contribute to greater spatial differentiation in the landscape and a higher quality of environmental life. The development of the Green-Blue Delta attempts to offer a basis for a system of smaller green-blue links with the mayor cities, becoming an attractive complement to sustainable urbanization. In Zuid-as project for example green spaces and 
water flows near Amsterdam will provide for a better and healthier living climate, in which city residents and visitors will enjoy more opportunities for leisure activities.

Already in the starting memo, the Randstad is analysed with the three dimensions of sustainability - people, planet, profit - and the layer approach - underground, networks and occupation - [14]. In recent policy plans, the traditional definition of sustainable development that deals with finding a good balance between the three P's has been supplemented by the forth component of Participation. In Zuid-as for example long-term urban interventions have been supported by collaborative approaches, based on the key objectives: energy, mobility, people and sharing of knowledge. Within the theme networks of the adopted layer approach in the Structural Vision for the Randstad, designers and planners have recently been produced a number of alternative scenarios for the positioning of program and infrastructure focusing on major cities [15].

Once again the dialectic relation between design and policy merged in a research report, providing a clear set of choices and models for the involved ministries, resulted in an exploration of the so-called Randstad Key Projects following from the Structural Vision. (Fig.1) The integration studio contains the lessons from the surveys, workshops and external studies, and the core recommendation: differentiate, integrate and calibrate. This opinion provides important input for the next step: the MIRT - in Dutch Multi Annual Program of Infrastructure, Space and Transport - that is an exploration program of Randstad Key Projects beyond 2020, translating some of the team's insights and ideas into the design tasks. Therefore the strategic infrastructural and urban developments to strengthen the National place-based policies [16] keep adopting flexible and multiscalar approaches, as it has been demonstrated in Amsterdam Zuidas, whose development process will take almost thirty years from now.

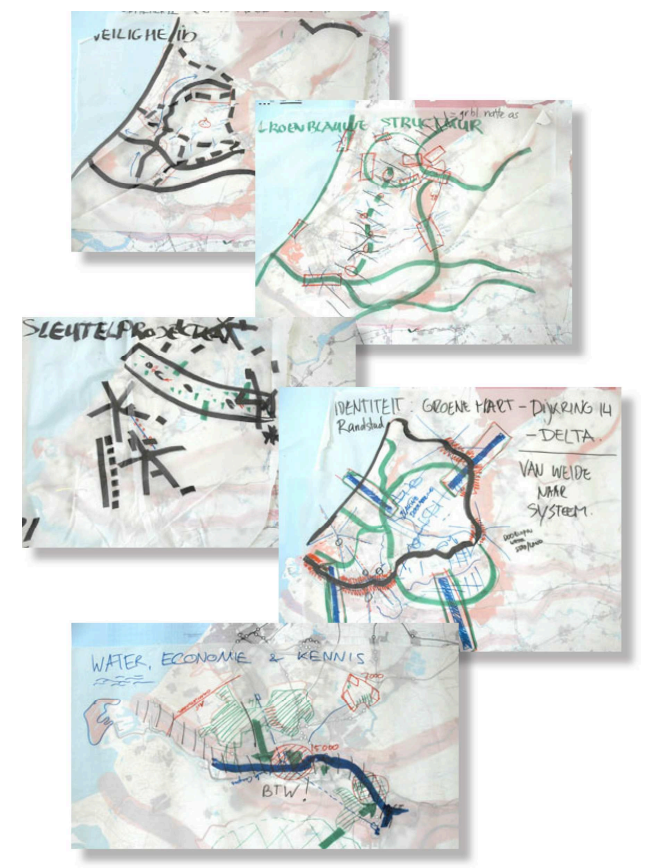

Fig. 1 Research-by-Design in Differentiëren, Calibreren en Integreren p.19 [15]

\section{Intermodal urban hub: Amsterdam Zuidas}

Within the above mention panorama, Amsterdam Zuidas constitutes a relevant case study of intermodal urban hub that the country is still developing to face the European metropolitan scale. [17] As a strategy for large-scale developments since the Plan Zuid of H.P. Berlage (1914) and the subsequent General Extension Plan of Van Esteren (1935), Zuidas acquires for Amsterdam 2040 Agenda a specific role in the reinforcement of the Netherlands within the international debate. Furthermore the spatial development policy report identifies it as a key urban project in the national network: a gateway for trade and transport related to international traffic flows. [18] The Zuidas 
location belongs to a complex urban system that looks at IJ-burg harbour area and Schiphol Airport as its ending appendices, while its central role lies in the intermodality, whose transport services include train, metro - mixed rapid transit and light rail -, tram and bus. (Fig. 2)

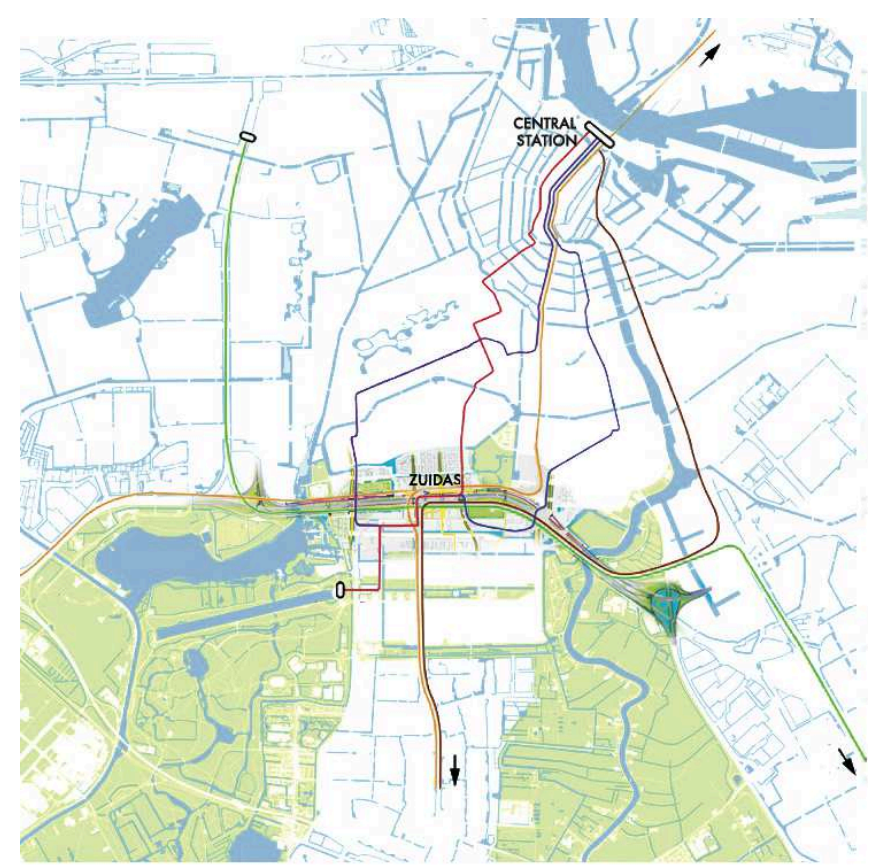

Fig. 2 Intermodal Urban Hub, based on the Ambition Document ZuidasDok [16]

On a larger scale Zuidas belongs to the Trans-European Network Program whose ambition to create a new European Metropolitan Space is embedded by the concept of infrastructural nodes comparable to world-class oriented cities over imposed to the urban structure. [19] The district works differently in appearance to the existing urban fabric, based on a transnational infrastructural scale strongly inter-connected to its physical background. The North/South metro line for example has been planned for the territorial extension from Amsterdam North, under the IJ River and the old centre, and ends at Amsterdam's South Station/World Trade Centre (Amsterdam Zuid/WTC) complex, a transit hub with rail links to Schiphol Airport, Den Haag and Rotterdam, and tram links to the growing South Axis commercial complex.

Since 1998 first proposals, the evolution of 'Zuid-as', Southern axis, focused on the construction of a large and stacked tunnel where infrastructure - highways, railway and high speed line - will pass together with the development of high density urban district. A parallel approach accompanied the design vision: the urbanisation of both sides of the infrastructural rest as a new landscape icon, and the relocation of infrastructure in the underground, together with a lack of a clear integrated strategy. It was the strategic plan approved by the City Council in April 2003 that defined the layer approach in Zuidas based on the overlay of green and water layer, roads, rail and cabling, built environment, together with the living culture, in terms of consultation with the population about the desired development of the city. In the new design approach, the Southern axis along the A10 ring road has been conceived as a top location within the city, as well as a city region core area, attracting major commercial investments at the Zuid Station. [20]

For a total area of 207 ha the proposed Dok Model, the disappearance of the A10 infrastructural bottleneck from the ground and the development of a new business district, with mixed-use buildings, bring together main private investors with the public sector for a total of 1.385 Million Euro expected investments. The increasingly conflict between the multiple actors appears evident within the complexity of contemporary governance policy that succeeded in the last decade in the project development. In this context of institutionally and financially complicated process of decision-making, the proposal still force to incorporate tunnels with mixed-use developments on the top. [21] In order to deal with uncertainties in economy and policy, the Zuidas-Dok Project 
Organization, cooperation with the Directorate General for Public Works and Water management, Prorail - government task organisation for maintenance and extension of the national railway network infrastructure -, the city Region and the city of Amsterdam, was established in mid 2010.

The public and private company presented Zuidas vision in the on going construction sites of high dense offices and mixed use buildings surrounding the infrastructural bundle. The underground Zuidas Dok model was preferred for its quality and because different options were difficult to implement in phases and insufficiently flexible. In the evolution of ideas about spatial organisation, important tools are the implementation of a more consistent network of open spaces and the overcoming of the infrastructure barrier, by integrating the north and south flanks as one urban core area. In practice, a step-by-step plan stretching over 20 years is envisaged, which keeps options open and flexible as long as possible, among others, on the infrastructure integration model, and which allows under any condition a maximum of development.

The latest Ambition Document ZuidasDok will give direction and strategic advice to the articulation of demand on the market to achieve the maximum possible ambitions within the budget cutbacks [22]. Public and private actors, together with technicians and designers, conducted a reality check on the draft document during workshops, roundtable and consultations, plus a digital survey of potential stakeholders and interested parties. At the present, negotiations between partners are being held about the feasibility of the Dok Model, providing the integrated framework for making choices, from the perspective of the relationship between infrastructure, city and country.

\section{Conclusions}

The project Zuidas, also known as Financial Mile, is facing the credit crisis without reaching a unique vision for its double design approach as new urban reality and intermodal hub. The complex infrastructural interface is now envisioned as urban basement instead of its original underground figurativeness, as well as the relation between urbanity and infrastructure seems to be a never ended decision-making process and open program. In this context, the Dok Model is a prime example of how major Dutch cities are readdressing the current generic vision Randstad 2040 and the desire to increase their metropolitan identity with strategic urban and architectural interventions as well as innovative sustainable approaches. Since 1998 the master plan has been developed gradually and constantly changed design in terms of sub-projects [23]; studies on the feasibility of different options have been simultaneously carried out.

The plan is now an open grid, a development strategy and a framework - in the spirit of flexible urban development. The priority has been given to the realization of the railway and the dock tunnel, together with a mixed suburb with many visitors and a mixed population for housing presence, different from La Defense idea. Finally the form, the function and the scope of urban policy and the rise of a new mode of urban governance look at the increasing involvement of private sector interests both in design and implementation [24]. Therefore the intermodal urban node Zuidas is a collection of artifacts (roads, buildings and infrastructure) with management activities between different actors (city councils, consultants, designers, stakeholders) and between city dreams (documented in plans and visions) and acts (as a result of actions of social actors); it arises then the question on how new metropolitan conditions will be developed all over European urban realities.

\section{References}

[1] C. Wagenaar: Town planning in the Netherlands since 1800: Responses to enlightenment ideas and geopolitical realities, 010 Publishers, Rotterdam (2011)

[2] P. Hall: The World Cities, Weidenfeld and Nicolson, London (1966)

[3] VROM: Ministry for Housing, Spatial Planning and the Environment of Netherlands, Structuurvisie Randstad 2040, VROM, Den Haag (2008) 
[4] VROM: Ministry for Housing, Spatial Planning and the Environment of Netherlands, Vierde Nota, VROM, Den Haag (1988)

[5] VROM: Ministry for Housing, Spatial Planning and the Environment of Netherlands, Vierde Nota Extra - VINEX, VROM, Den Haag (1991)

[6] J. W. Neutelings: The Patchwork Metropolis. Information on http://www.neutelingsriedijk.com

[7] OMA: Pointcity Southcity, Netherlands, An investigation into the re-planning of the Netherlands, in: Koolhaas, H. Werlemann and B. Mau, S,M,L,XL, The Monacelli Press, New York (1994)

[8] VROM: Ministry for Housing, Spatial Planning and the Environment of Netherlands, Vijfde Nota 2000/2020, VROM, Den Haag (2000)

[9] D. Van Dansik, M. Bouw: Deltametropool. Study of the Randstad as a single city. In: Pasajes de arquitectura y critica, vol. 49, 2(003)

[10] Deltametropool Design Studio (teams OMA, H+N+S, TKA, Luigi Snozzi): report ontwerpatelier Deltametropool, (2005). Information on http://www.rijksoverheid.nl

[11] VROM: Ministry for Housing, Spatial Planning and the Environment of Netherlands, Nota Ruimte, Ruimte voor ontwikkeling, VROM, Den Haag (2005)

[12] J. J. Trip: Urban Quality in High-speed Train Station Area Redevelopment: The Cases of Amsterdam Zuidas and Rotterdam Centraal, in: Planning Practice \& Research, 23:3, DOI (2008)

[13] OECD: Organisation for Economic Cooperation and Development, Green Growth Studies Compact City Policies A Comparative Assessment: A Comparative Assessment, OECD Publishing, Paris, (2012), p. 262

[14] VROM: Ministry for Housing, Spatial Planning and the Environment of Netherlands, Startnotitie Randstad 2040, VROM, Den Haag, (2007). Information on http://www.rijksoverheid.nl

[15] M. Bouw (One Architecture) and R. de Graaf (OMA): Differentiëren, Calibreren en Integreren Ontwerpende verkenning naar sleutelprojecten in het kader van de Structuurvisie Randstad 2040, VROM, Den Haag, (2009). Information on http://www.rijksoverheid.nl

[16] OECD: Organisation for Economic Cooperation and Development, National Place-based Policies in the Netherlands, OECD Publishing, Paris, (2010)

[17] W. G. M. Salet, S. Majoor: Amsterdam Zuidas European Space. Rotterdam: 010 Publ., (2005)

[18] VROM: Ministry for Housing, Spatial Planning and the Environment of Netherlands, Vierde Nota Extra, Nationale Sleutelprojecten, VROM, Den Haag, (1997)

[19] F. Berlingieri, M. Triggianese: From Utopia to Real World. Construction of a Unique Metropolitan Space of Europe, in: Monu, vol. 19, Rotterdam, (2013)

[20] P. Healey: Urban Complexity and Spatial Strategies: Towards a Relational Planning for our Times, Routledge, London, (2007)

[21] S. J. H. Majoor: Disconnected innovations: new urbanity in large-scale development projects. Zuidas Amsterdam, Ørestad Copenhagen and Forum Barcelona, dissertation, Faculty of Social and Behavioural Sciences, Amsterdam, 2008, p. 268. Information on http://dare.uva.nl 
[22] DRO: City of Amsterdam Physical Planning Department, Zuidas Vision Document, City of Amsterdam, (2009). Information on www.amsterdam.nl/zuidas

[23] L. Bertolini, T. Spit: Cities on Rails: The Redevelopment of Railway Station Areas, London: Spon, 1998, p.111

[24] S. Rizal: Managing Collaborative Design, Eburon Uitgeverij B.V. (2007) 